\title{
A New Case of the Rare 10q22.3q23.2 Microdeletion Flanked by Low-Copy Repeats 3/4
}

\author{
Miriam Coelho Molck Milena Simioni Társis Paiva Vieira \\ Fabíola Paoli Monteiro Vera L. Gil-da-Silva-Lopes
}

Department of Medical Genetics, Faculty of Medical Sciences, University of Campinas (UNICAMP), Campinas, Brazil

\section{Established Facts}

- Reported 10q22.3q23.2 microdeletions are associated with the recently described and rare 10q22q23 deletion syndrome with an uncharacteristic phenotype.

- To date, 14 microdeletions at 10q22.3q23.2 flanking low-copy repeats 3/4 have been reported in the literature.

\section{Novel Insights}

- We report on a new case of a boy presenting with a 7.8-Mb microdeletion at 10q22.3q23.2 and compare his clinical signs with similar cases reported in the literature.

- In addition, our patient has a microdeletion at $16 \mathrm{q} 12.1$ of $189 \mathrm{~kb}$ that could be related to the phenotype.

\section{Key Words}

Deletion syndrome 10q22q23 - Genotype-phenotype correlation · Molecular cytogenetics

\begin{abstract}
Deletions in the $10 q 22.3 q 23.2$ region are rare and mediated by 2 low-copy repeats (LCRs 3 and 4). These deletions have already been recognized as the $10 q 22 q 23$ deletion syndrome. The phenotype associated with this condition is rather uncharacteristic, and most common features are craniofacial dysmorphisms and developmental delay. We describe a boy with craniofacial dysmorphic features, developmental delay, tetralogy of Fallot, hand/foot abnormalities,
\end{abstract}

(c) 2017 S. Karger AG, Basel

\section{KARGER}

E-Mail karger@karger.com

www.karger.com/msy and recurrent respiratory tract infections. Chromosomal microarray analysis disclosed a $7.8-\mathrm{Mb}$ microdeletion at $10 q 22.3 q 23.2$, flanked by LCRs 3/4, and an additional $16 q 12.1$ microdeletion of $189 \mathrm{~kb}$. This article reviews the clinical signs of reported cases with similar deletions and compares them with our patient, contributing to a better understanding of genotype-phenotype correlation.

(c) 2017 S. Karger AG, Basel

The improvement of molecular cytogenetic analyses, including the use of MLPA and chromosomal microarray techniques, has shown that the list of microdeletion/ microduplication syndromes is constantly increasing

Vera L. Gil-da-Silva-Lopes

Department of Medical Genetics, Faculty of Medical Sciences, University of Campinas Tessália Vieira de Camargo Street, 126

Campinas, SP 13083-887 (Brazil)

E-Mail vlopes@fcm.unicamp 


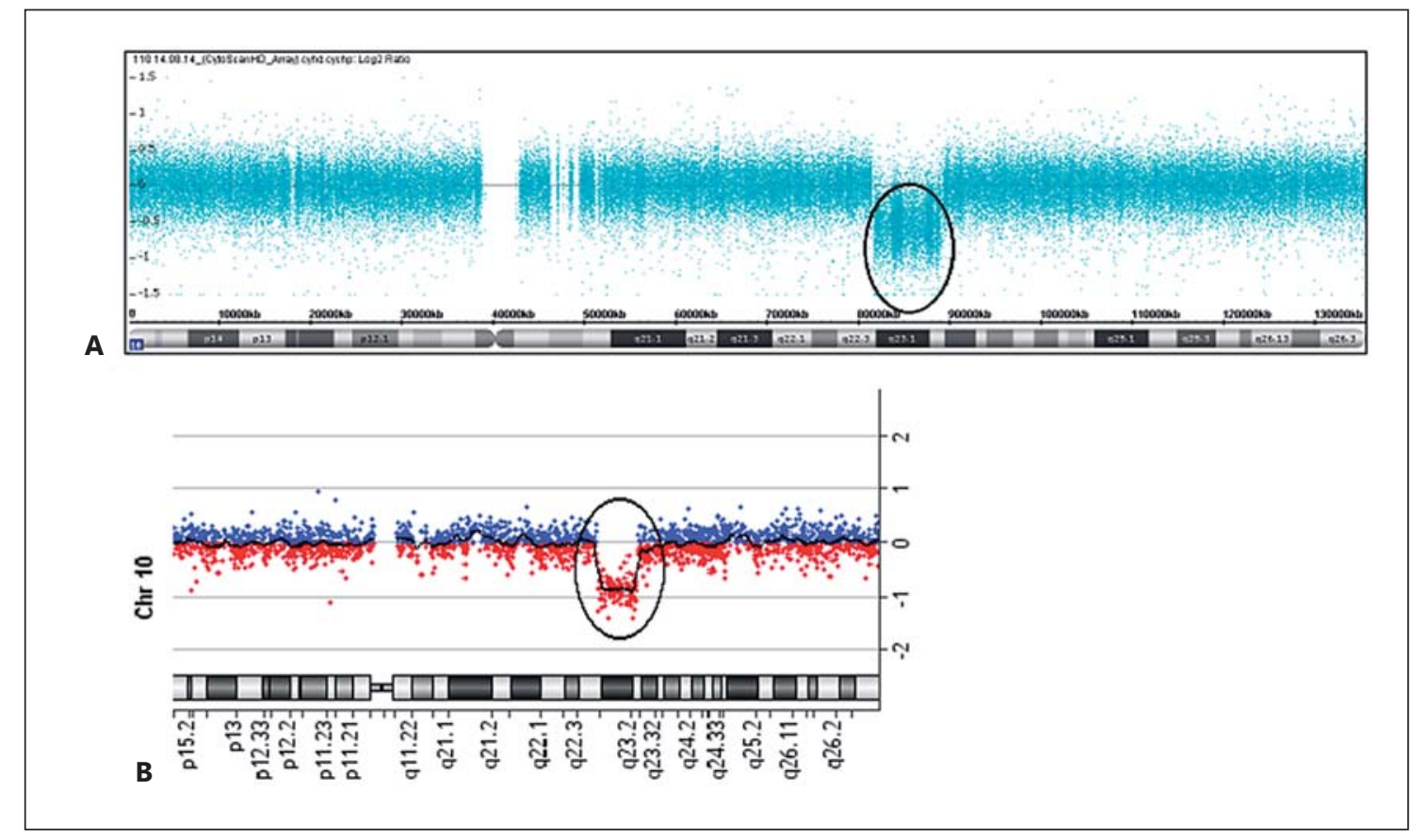

Fig. 1. Array results of the affected individual. A Chromosomal microarray analysis (CMA) hybridization profile of chromosome 10 using the CytoScan HD chip indicating a 7.8-Mb microdeletion at q22.3q23.2 (81,446,57789,253,430; hg 19). B CMA hybridization profile of chromosome 10 using Agilent Human Genome G3 SurePrint $8 \times 60 \mathrm{~K}$ microarray confirming the q22.3q23.2 microdeletion.

[Slavotinek, 2008; Nevado et al., 2014]. Some of these have a recognizable phenotype; others have less consistent phenotypes and are associated with an increased risk of neuropsychiatric disorders [Koolen et al., 2008; van Bon et al., 2011].

Deletions of 10q22.3q23.2 have been characterized as a rare new syndrome associated with cognitive impairment and behavioral abnormalities [Balciuniene et al., 2007]. This region is flanked by a complex set of low-copy repeats (LCRs), designed LCR3 and LCR4, which can give rise to various genomic changes mediated by nonallelic homologous recombination (NAHR) [Lupski and Stankiewicz, 2005].

The presence of LCRs in this region suggests that this locus has an increased susceptibility to chromosomal rearrangements [Alliman et al., 2010]. Nevertheless, only 14 novel deletions and 7 duplications with breakpoints within LCRs 3/4 have been described [Goss et al., 1998; Han et al., 2004; Dufke et al., 2006; Balciuniene et al., 2007; Erdogan et al., 2008; Alliman et al., 2010; Reddy et al., 2011; Singh et al., 2011; van Bon et al., 2011; Petrova et al., 2014].
In this study, we report on a patient carrying a microdeletion of $7.8 \mathrm{Mb}$ at 10q22.3q23.2, flanked by LCRs 3/4, and in addition, a 189-kb microdeletion at 16q12.1.

\section{Patient and Method}

Case Report

A 3-year-old boy was referred for medical genetics consultation at the Genetic Service of FCM-UNICAMP because of multiple anomalies. He was evaluated by experienced clinical geneticists with a specific checklist comprising clinical and family history information and dysmorphic features.

The proband is the second child born to nonconsanguineous parents with a previous spontaneous abortion and an older healthy child. His family history was unremarkable. At birth, he was noted to have bilateral clubfeet. During the neonatal period, tetralogy of Fallot was diagnosed, and at 9 months of age, corrective cardiac surgery was performed. His subsequent development was globally delayed, and a single febrile convulsion was reported during childhood. Also, he was noted to have recurrent upper airway infections.

Dysmorphology examination at the age of 3 years revealed: frontal bossing, low-set and slightly anteverted ears with bilateral overfolded helix and prominent right antihelix, right preauricular pit, mildly sparse eyebrows, downslanting palpebral fissures, shallow orbits, bulbous tip of the nose, high-arched palate, bilateral clubfeet, and bilateral incomplete palmar creases. 


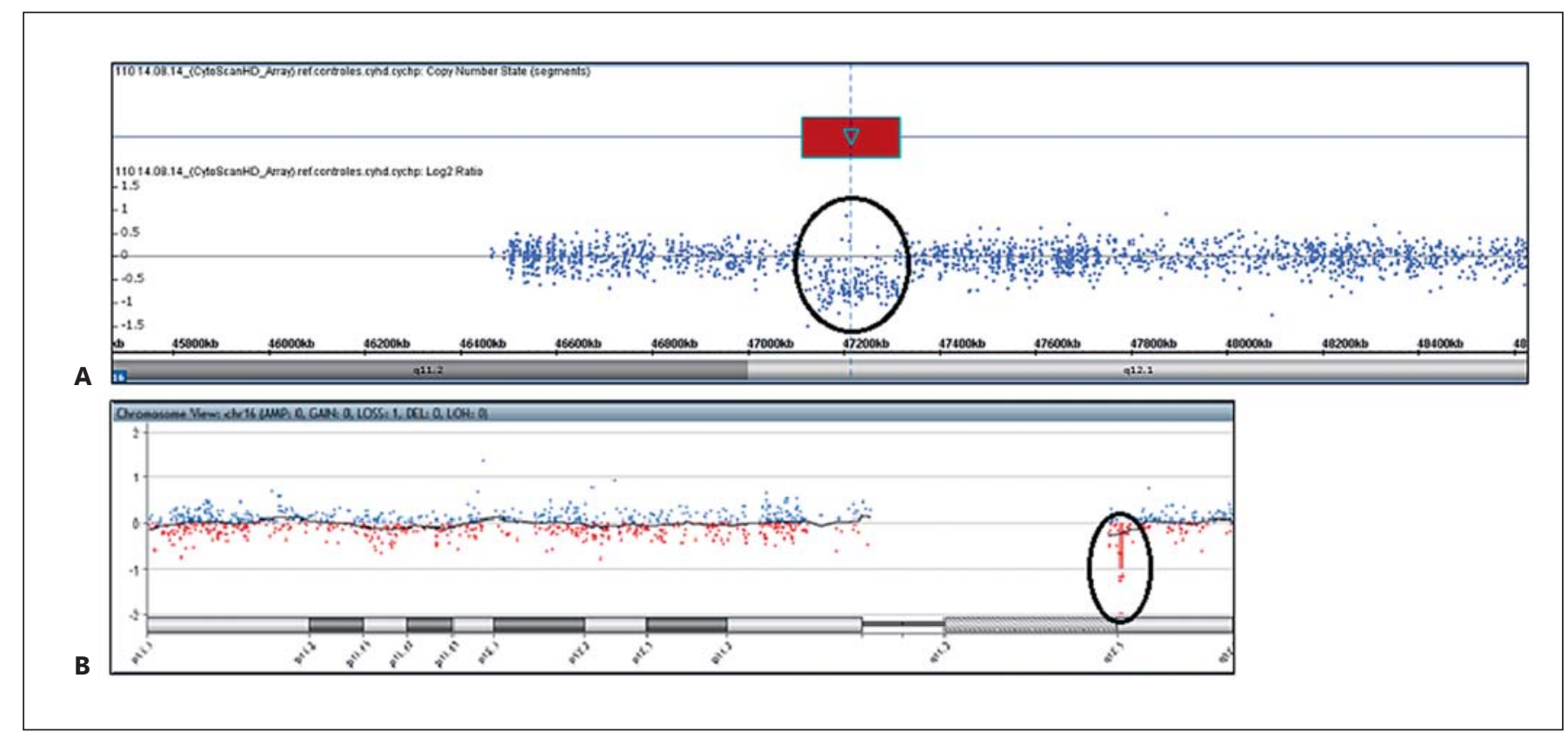

Fig. 2. Array results of affected individual. A Chromosomal microarray analysis (CMA) hybridization profile of chromosome 16 using CytoScan HD chip indicating a 189-kb microdeletion at q12.1 (47,127,281-47,316,339; hg 19). B CMA hybridization profile of chromosome 16 using Agilent Human Genome G3 SurePrint $8 \times 60 \mathrm{~K}$ microarray confirming the q12.1 microdeletion.

Molecular Cytogenetic Analysis

Chromosomal microarray analysis was performed using the CytoScan HD chip (Affymetrix, Santa Clara, CA, USA), following the manufacturer's instructions, and analyzed with the Chromosome Analysis Suite (ChAS) Software (Affymetrix). Confirmation of pathogenic CNVs was performed with the Agilent Human Genome G3 SurePrint $8 \times 60 \mathrm{~K}$ Microarray (Agilent Technologies, Santa Clara, CA, USA) and analyzed with the Agilent Cytogenomics software (Agilent Technologies).

Chromosomal microarray analysis of the patient revealed a microdeletion of $7.8 \mathrm{Mb}$ at 10q22.3q23.2 (Fig. 1A, B). Additionally, our patient had a $189-\mathrm{kb}$ microdeletion at $16 \mathrm{q} 12.1$ (Fig. 2A, B): $\operatorname{arr}[$ GRCh37] 10q22.3q23.2(81446577_89253430) $\times 1,16 q 12.1\left(47127281 \_47316339\right) \times 1$. An investigation of the parental origin of these deletions was not possible because samples were not available. The patient lost follow-up and the karyotype could not be performed to exclude structural changes.

\section{Discussion}

We report on the case of a boy with developmental delay, congenital heart disease (CHD), craniofacial dysmorphic features, hand/foot abnormalities, and recurrent infections. Indeed, the patient presents with a 7.8Mb 10q22.3q23.2 interstitial microdeletion overlapping the region of the rare $10 \mathrm{q} 22 \mathrm{q} 23$ deletion syndrome (DS).

10q22q23 Microdeletion
The common clinical features of the reported patients and our proband with LCRs 3/4 10q22.3q23.2 deletion included: craniofacial dysmorphic features, present in all 15 patients, developmental delay $(13 / 15,87 \%)$, palate alterations $(6 / 15,40 \%)$, CHD $(6 / 15,40 \%)$, and hand/foot abnormalities $(10 / 15,67 \%)$. Other less common clinical features of the 10q22q23 DS not present in our patient are: hypotonia $(3 / 15,20 \%)$, autism $(2 / 15,13 \%)$ and joint hyperextensibility $(2 / 15,13 \%)$ (Table 1$)$.

The craniofacial dysmorphisms do not result in a recognizable facial phenotype and included most commonly hypo- or hypertelorism (9/15,60\%), low-set and small ears $(6 / 15,40 \%)$, up- or downslanting palpebral fissures $(6 / 15,40 \%)$, epicanthic folds $(4 / 15,27 \%)$, and a flat nasal bridge $(3 / 15,20 \%)$. Our patient presented with low-set ears and downslanting palpebral fissures.

The most common palate alteration is a high-arched palate present in 5 of 15 patients (33\%), including the one reported here. The most frequently observed CHD are ventricular septal defects identified in 3 of 15 patients (20\%), but not found in our patient in whom tetralogy of Fallot was detected. Hand/foot abnormalities commonly included club feet $(4 / 15,27 \%)$, also present in our patient, and arachnodactyly $(2 / 15,13 \%)$. Another clinical feature 
Table 1. Clinical features of patients with 10q22.3q23.3 deletion flanking LCRs 3/4

\begin{tabular}{|c|c|c|c|c|c|c|c|c|c|c|c|}
\hline $\begin{array}{l}\text { References, } \\
\text { cases }\end{array}$ & $\begin{array}{l}\text { Deletion } \\
\text { size }\end{array}$ & Inheritance & Gender & $\begin{array}{l}\text { Age at } \\
\text { evaluation }\end{array}$ & $\mathrm{DD}$ & CHD & $\begin{array}{l}\text { Palate } \\
\text { alterations }\end{array}$ & Craniofacial dysmorphic features & $\begin{array}{l}\text { Hand/foot } \\
\text { alterations }\end{array}$ & $\begin{array}{l}\text { Other clinical } \\
\text { features }\end{array}$ & $\begin{array}{l}\text { Additional } \\
\text { aberrations }\end{array}$ \\
\hline \multicolumn{12}{|c|}{ Balciuniene et al. [2007] } \\
\hline UM10qDel-01 & $7.5 \mathrm{Mb}$ & maternal & male & $3 \mathrm{ys}, 6 \mathrm{~m}$ & + & - & - & mild features & - & autism & - \\
\hline JHU10qDel-01 & $7.5 \mathrm{Mb}$ & de novo & male & $1 \mathrm{y}, 6 \mathrm{~m}$ & + & - & - & white forelock & - & $\begin{array}{l}\text { retrocerebellar } \\
\text { cyst, small } \\
\text { cerebellum }\end{array}$ & - \\
\hline \multicolumn{12}{|c|}{ Alliman et al. [2010] } \\
\hline Case 1 & $7.25 \mathrm{Mb}$ & de novo & male & $2 \mathrm{ys}, 7 \mathrm{~m}$ & + & PDA & $\begin{array}{l}\text { high- } \\
\text { arched } \\
\text { palate }\end{array}$ & $\begin{array}{l}\text { mild hypertelorism, upslanting palpebral } \\
\text { fissures, overfolding of lateral pinna, earlo- } \\
\text { be creases, thin upper lip, micrognathia }\end{array}$ & arachnodactyly & $\begin{array}{l}\text { autism, joint } \\
\text { hyper- } \\
\text { extensibility }\end{array}$ & - \\
\hline Case 2 & $7.25 \mathrm{Mb}$ & de novo & female & $17 \mathrm{ys}, 1 \mathrm{~m}$ & + & - & $\begin{array}{l}\text { high- } \\
\text { arched } \\
\text { palate }\end{array}$ & $\begin{array}{l}\text { mild facial asymmetry, downslanting } \\
\text { palpebral fissures, borderline set ears, } \\
\text { malar flattening, prognathism }\end{array}$ & $\begin{array}{l}\text { mild } \\
\text { arachnodactyly }\end{array}$ & $\begin{array}{l}\text { mild hypotonia, } \\
\text { joint hyper- } \\
\text { extensibility, } \\
\text { history of } \\
\text { myopia, ADHD }\end{array}$ & - \\
\hline Case 3 & $7.25 \mathrm{Mb}$ & de novo & male & 8 days & NA & - & - & $\begin{array}{l}\text { normocephalic with mild plagiocephaly, } \\
\text { hypertelorism, mild epicanthic folds, } \\
\text { low-set, posteriorly rotated ears, narrow } \\
\text { ear canals }\end{array}$ & $\begin{array}{l}\text { bilateral } \\
\text { clubfeet }\end{array}$ & $\begin{array}{l}\text { mild hypotonia, } \\
\text { bilateral hearing } \\
\text { loss }\end{array}$ & - \\
\hline Case 4 & $7.25 \mathrm{Mb}$ & de novo & male & $1 \mathrm{y}, 8 \mathrm{~m}$ & + & - & $\begin{array}{l}\text { high- } \\
\text { arched } \\
\text { palate }\end{array}$ & $\begin{array}{l}\text { macrocephaly, frontal bossing, narrow } \\
\text { philtrum, retrognathia, small mouth, } \\
\text { downslanting palpebral fissures, hyper- } \\
\text { telorism, small swept-back ears, bilateral } \\
\text { notch mid helix }\end{array}$ & - & $\begin{array}{l}\text { mild hypotonia, } \\
\text { failure to thrive }\end{array}$ & - \\
\hline \multicolumn{12}{|c|}{ van Bon et al. [2011] } \\
\hline Patient 1 & $7.2 \mathrm{Mb}$ & de novo & female & $22 \mathrm{ys}$ & + & - & - & $\begin{array}{l}\text { hypotelorism, upslanting palpebral } \\
\text { fissures, ptosis, low-set small ears }\end{array}$ & $\begin{array}{l}\text { broad thumbs } \\
\text { and halluxes }\end{array}$ & breast aplasia & - \\
\hline Patient 2 & $7.2 \mathrm{Mb}$ & unknown & female & $2 \mathrm{ys}, 6 \mathrm{~m}$ & + & AVSD & - & $\begin{array}{l}\text { hypertelorism, anteverted nares, flat } \\
\text { nasal bridge, large mouth, telecanthus, } \\
\text { low-set ears }\end{array}$ & - & - & - \\
\hline Patient 3 & $7.7 \mathrm{Mb}$ & de novo & male & $3 \mathrm{ys}, 7 \mathrm{~m}$ & + & - & $\begin{array}{l}\text { high- } \\
\text { arched } \\
\text { palate }\end{array}$ & $\begin{array}{l}\text { dolichocephaly, hypertelorism, epicanthal } \\
\text { folds, flat nasal bridge, midface retraction, } \\
\text { low-set prominent ears }\end{array}$ & $\begin{array}{l}\text { retroplaced } \\
\text { thumbs }\end{array}$ & $\begin{array}{l}\text { maligned } \\
\text { teeth, Chiari I } \\
\text { malformation, } \\
\text { epilepsy }\end{array}$ & $\begin{array}{l}\text { de novo } \\
2 \mathrm{q} 36.3 \\
\text { dupli- } \\
\text { cation } \\
(722 \mathrm{~kb})\end{array}$ \\
\hline Patient 4 & $7.7 \mathrm{Mb}$ & de novo & male & $12 \mathrm{ys}$ & + & TR, PR & - & $\begin{array}{l}\text { long face, hypertelorism, almond-shaped } \\
\text { eyes }\end{array}$ & $\begin{array}{l}\text { radioulnar } \\
\text { synostosis, } \\
\text { scoliosis, } \\
\text { kyphosis, pectus } \\
\text { excavatum }\end{array}$ & $\begin{array}{l}\text { café-au-lait } \\
\text { spots }\end{array}$ & $47, \mathrm{XYY}$ \\
\hline Patient 5 & $7.5 \mathrm{Mb}$ & maternal & male & 5 ys & + & - & - & $\begin{array}{l}\text { hypertelorism, broad base of nose, flat } \\
\text { nasal bridge, low-set ears }\end{array}$ & $\begin{array}{l}\text { bilateral } \\
\text { clubfeet }\end{array}$ & shawl scrotum & - \\
\hline \multicolumn{12}{|c|}{ Reddy et al. [2011] } \\
\hline Case 2 & $7.7 \mathrm{Mb}$ & de novo & female & 4 ys & + & - & - & $\begin{array}{l}\text { broad nose, everted lower lip vermillion } \\
\text { border }\end{array}$ & - & - & - \\
\hline \multicolumn{12}{|c|}{ Singh et al. [2011] } \\
\hline Case report & $7.46 \mathrm{Mb}$ & de novo & female & $5 \mathrm{ys}, 6 \mathrm{~m}$ & + & VSD & - & mild epicanthic folds, right-sided exotropia & $\begin{array}{l}\text { hyperkeratosis } \\
\text { of the fifth } \\
\text { toenail }\end{array}$ & $\begin{array}{l}\text { persistent } \\
\text { tachypnea, } \\
\text { recurrent middle } \\
\text { ear infections }\end{array}$ & - \\
\hline \multicolumn{12}{|c|}{ Petrova et al. [2014] } \\
\hline Clinical report & $7.3 \mathrm{Mb}$ & de novo & male & 2 ys & - & $\begin{array}{l}\text { VSD, } \\
\text { PFO }\end{array}$ & $\begin{array}{l}\text { median } \\
\text { cleft } \\
\text { palate }\end{array}$ & $\begin{array}{l}\text { hypertelorism, high forehead, broad nasal } \\
\text { bridge, upslanting palpebral fissures, } \\
\text { epicanthic folds, retrognathia, glossoptosis }\end{array}$ & $\begin{array}{l}\text { right-sided } \\
\text { clubfoot }\end{array}$ & - & - \\
\hline Current case & $7.8 \mathrm{Mb}$ & unknown & male & 3 ys & + & TOF & $\begin{array}{l}\text { high- } \\
\text { arched } \\
\text { palate }\end{array}$ & $\begin{array}{l}\text { frontal bossing, low-set and slightly ante- } \\
\text { verted ears with bilateral overfolded helix } \\
\text { and prominent right antihelix, right preau- } \\
\text { ricular pit, mildly sparse eyebrows, down- } \\
\text { slanting palpebral fissures, shallow orbits, } \\
\text { bulbous tip of the nose }\end{array}$ & $\begin{array}{l}\text { bilateral } \\
\text { clubfeet, } \\
\text { bilateral } \\
\text { incomplete } \\
\text { palmar creases }\end{array}$ & $\begin{array}{l}\text { recurrent } \\
\text { upper } \\
\text { respiratory } \\
\text { tract infections }\end{array}$ & $\begin{array}{l}16 \mathrm{q} 12.1 \\
\text { deletion } \\
(189 \mathrm{~kb})\end{array}$ \\
\hline
\end{tabular}

ADHD, attention deficit/hyperactive disorder; AVSD, atrial ventricular septal defect; CHD, congenital heart disease; DD, developmental delay; m, months; NA, not available; PDA, patent ductus arteriosus; PFO, persistent foramen ovale; PR, pulmonic regurgitation; TOF, tetralogy of Fallot; TR, tricuspid regurgitation; VSD, ventricular septal defect; ys, years; +, present; -, absent.

Mol Syndromol 2017;8:161-167
DOI: $10.1159 / 000469965$
Coelho Molck/Simioni/Paiva Vieira/

Paoli Monteiro/Gil-da-Silva-Lopes 
observed in our patient was recurrent upper respiratory tract infections, not reported in other 10q22q23 DS cases.

There are 16 OMIM genes within the 7.8-Mb-deleted region at $10 \mathrm{q} 22.3 \mathrm{q} 23.2$ detected in our patient. Some of these genes, e.g., BMPR1A (601299), LDB3 (605906), GRID1 (610659), and NRG3 (605533), have been hypothesized as putative candidate genes associated with the phenotype, especially regarding the neuropsychological development and cardiac defects [Balciuniene et al., 2007; van Bon et al., 2011; Breckpot et al., 2012].

Saito et al. [2012] evaluated heart morphology of the mutant mouse knockout BMPR1A protein in neuralcrest-derived cells and showed that some of them exhibited facial fusion defects such as a cleft face and cleft palate, or facial dysmorphic features besides heart defects. Thus, the craniofacial dysmorphisms and CHD observed in our patient may be partly caused by the deletion in the $B M P R 1 A$ gene.

Heterozygous point mutations or partial deletions of the BMPR1A gene are also associated with the juvenile polyposis syndrome (OMIM 174900), characterized by developing hamartomatous polyps in the gastrointestinal tract [Larsen and Howe, 2017]. Among patients with 10q22.3q23.2 deletions, one subtype of the juvenile polyposis syndrome, called juvenile polyposis of infancy, has been observed only in those having both BMPR1A and PTEN genes deleted [Menko et al., 2008]. PTEN has a recognized tumor suppressor role [Li et al., 1997] and is associated with Cowden syndrome and Bannayan-RileyRuvalcaba syndrome, suggesting that contiguous deletion of both BMPR1A and PTEN is required for polyposis development [Zhou et al., 2003; Dahdaleh et al., 2012]. PTEN is not present in LCR 3/4-flanked 10q22.3q23.2 deletion and none of the patients with similar deletions were reported to have juvenile polyposis of infancy or to have developed the polyposis phenotype [Petrova et al., 2014].

LDB3 encodes a LIM-binding domain 3 protein which is involved in cytoskeletal assembly, and mutations in this gene have been associated with dilated cardiomyopathy in humans [Vatta et al., 2002; Hershberger et al., 2008]. The impact of this protein in the function or structure of the heart is under investigation [Alliman et al., 2010].

The GRID1 gene encodes a subunit of glutamate receptor channels, which have a role in mediating excitatory synaptic transmission in the central nervous system [Yamazaki et al., 1992]. Vasan et al. [2009] proposed GRID1 as a candidate gene for left ventricle wall thickness through a genome-wide association meta-analysis of common genetic variants associated with cardiac structure and function. In addition, this gene has also been as-

10q22q23 Microdeletion sociated with schizophrenia in several studies [Fallin et al., 2005; Coyle, 2006; van Bon et al., 2011]. Another gene located proximal of GRID1 and reportedly associated with schizophrenia risk and presentation is NRG3 [Chen et al., 2009], which has a role in signaling proteins that mediate cell-cell interactions in the nervous system, heart, breast, and other organ systems [Falls, 2003].

In addition, our patient has a microdeletion in $16 \mathrm{q} 12.1$ $(189 \mathrm{~kb})$. This region includes 2 OMIM genes: NETO2 (607974) and ITFG1 (611803). NETO2 is a kainate receptor subunit proposed to have significant effects on glutamate signaling mechanisms in the brain [Zhang et al., 2009]. ITFG1 is a transmembrane protein with proposed cellular adhesion function [Kato et al., 2014]. This deletion was not detected among individuals in the DGV database (http://projects.tcag.ca/variation). In the DECIPHER database (https://decipher.sanger.ac.uk/), much larger deletions encompassing the one found in our patient have been described as a sole finding in 2 individuals (2856 and 289229) presenting with developmental delay in common with our patient. Also, the case 289229 from DECIPHER presented with CHD, an atrial septal defect. To determine the significance of this deletion on the phenotype, more information about other individuals carrying similar deletions and especially more information about the specific functions of these genes are needed.

Additional chromosome abnormalities were observed in 3 of 15 patients with 10q22q23 DS (Table 1) and may have influenced the phenotype. Recently, it has been suggested that large genomic-scale structural variants, i.e., alterations involving megabases of DNA, can be associated with additional complexities, such as other structural variants that are generated in a one-off event (chromoanasynthesis- and chromothripsis-like events) or a complex genomic rearrangement accompanied by absence of heterozygosity [Carvalo and Lupski, 2016]. Distinct disease phenotypes affect different organ systems, whereas overlapping disease phenotypes are more likely to be caused by 2 genes encoding proteins that interact within the same pathway. This interplay between pathogenic variants in multiple genes results in the complex spectrum observed on phenotypes within one patient and contributes to the variability of the associated genomic disorder [Posey et al., 2017].

Most of the clinical signs present in our patient are reported in the rare 10q22q23 DS. However, the findings in our patient and in others carrying this deletion do not allow the characterization of a core phenotype. In addition, we cannot exclude the influence of the 16q12.1 deletion on the phenotype.

Mol Syndromol 2017;8:161-167 DOI: $10.1159 / 000469965$ 
The identification of rare and new genomic imbalances in young patients can change clinical management by allowing early intervention for behavioral abnormalities and developmental delay also ensuring a specific followup. Additional cases would improve the genotype-phenotype correlation and the effect of multiple rare variants on the etiology of this disorder.

\section{Acknowledgments}

We acknowledge the patient and his family for their cooperation and the Laboratory of Multiuser Equipment in the Laboratory of Molecular Genetics, Faculty of Medical Sciences, University of Campinas, located in Campinas, São Paulo, Brazil for their support with the use of equipment, GeneChip Fluidics Station, and GeneChip Scanner.

This study was supported by FAPESP - Fundação de Amparo à Pesquisa do Estado de São Paulo (2008/10596-0, 2009/08756-1, and 2011/23794-7, 2012/51799-6) and CNPq - Conselho Nacional de Desenvolvimento Científico e Tecnológico (149600/2010-0 and 471422/2011-8). V.L.G.-d.-S.-L. is supported by CNPq (304455/ 2012-1).

\section{Statement of Ethics}

This study was approved by the Ethics Committee Board of the University of Campinas (Nos. 487/2009 and 433/2010). Written informed consent was obtained from the patient's parents.

\section{Disclosure Statement}

The authors declare no potential conflicts of interest with respect to the research, authorship, and/or publication of this article.

\section{References}

Alliman S, Coppinger J, Marcadier J, Thiese H, Brock P, et al: Clinical and molecular characterization of individuals with recurrent genomic disorder at 10q22.3q23.2. Clin Genet 78:162-168 (2010).

Balciuniene J, Feng N, Iyadurai K, Hirsch B, Charnas L, et al: Recurrent 10q22-q23 deletions: a genomic disorder on $10 \mathrm{q}$ associated with $\mathrm{cog}$ nitive and behavioral abnormalities. Am J Hum Genet 80:938-947 (2007).

Breckpot J, Tranchevent LC, Thienpont B, Bauters $\mathrm{M}$, Troost $\mathrm{E}$, et al: BMPR1A is a candidate gene for congenital heart defects associated with the recurrent $10 \mathrm{q} 22 \mathrm{q} 23$ deletion syndrome. Eur J Med Genet 55:12-16 (2012).

Carvalho CM, Lupski JR: Mechanisms underlying structural variant formation in genomic disorders. Nat Rev Genet 17:224-238 (2016).

Chen PL, Avramopoulos D, Lasseter VK, McGrath JA, Fallin MD, et al: Fine mapping on chromosome 10q22-q23 implicates neuregulin 3 in schizophrenia. Am J Hum Genet 84: 21-34 (2009).

Coyle JT: Glutamate and schizophrenia: beyond the dopamine hypothesis. Cell Mol Neurobiol 26:365-384 (2006).

Dahdaleh FS, Carr JC, Calva D, Howe JR: Juvenile polyposis and other intestinal polyposis syndrome with microdeletions of chromosome 10q22-23. Clin Genet 81:110-116 (2012).

Dufke A, Singer S, Borell-Kost S, Stotter M, Pflumm DA, et al: De novo structural chromosomal imbalances: molecular cytogenetic characterization of partial trisomies. Cytogenet Genome Res 114:342-350 (2006).
Erdogan F, Belloso JM, Gabau E, Ajbro KD, Guitart $M$, et al: Fine mapping of a de novo interstitial 10q22-q23 duplication in a patient with congenital heart disease and microcephaly. Eur J Med Genet 51:81-86 (2008).

Fallin MD, Lasseter VK, Avramopoulos D, Nicodemus KK, Wolyniec PS, et al: Bipolar I disorder and schizophrenia: a 440-singlenucleotide polymorphism screen of 64 candidate genes among Ashkenazi Jewish caseparent trios. Am J Hum Genet 77:918-936 (2005).

Falls DL: Neuregulins: functions, forms, and signaling strategies. Exp Cell Res 284:14-30 (2003).

Goss PW, Voullaire L, Gardner RJ: Duplication 10q22.1 eq25.1 due to intrachromosomal insertion: a second case. Ann Genet 41:161-163 (1998).

Han JY, Kim KH, Jun HJ, Je GH, Glotzbach CD, Shaffer LG: Partial trisomy of chromosome 10(q22-q24)due to maternal insertional translocation $(15 ; 10)$. Am J Med Genet A 131: 190-193 (2004).

Hershberger RE, Parks SB, Kushner JD, Li D, Ludwigsen $\mathrm{S}$, et al: Coding sequence mutations identified in MYH7, TNNT2, SCN5A, CSRP3, LBD3, and TCAP from 313 patients with familial or idiopathic dilated cardiomyopathy. Clin Transl Sci 1:21-26 (2008).

Kato M, Chou TF, Yu CZ, DeModena J, Sternberg PW: LINKIN, a new transmembrane protein necessary for cell adhesion. Elife 3:e04449 (2014).

Koolen DA, Sharp AJ, Hurst JA, Firth HV, Knight SJ, et al: Clinical and molecular delineation of the $17 \mathrm{q} 21.31$ microdeletion syndrome. J Med Genet 45:710-720 (2008).
Larsen HJ, Howe JR: Juvenile polyposis syndrome, in Pagon RA, Adam MP, Ardinger $\mathrm{HH}$, Wallace SE, Amemiya A, et al (eds): GeneReviews $^{\circledR}$ [Internet] (University of Washington, Seattle 1993-2017). Initial posting: 2003 May 13; last update: 2015 Dec 3.

Li J, Yen C, Liaw D, Podsypanina K, Bose S, et al: $P T E N$, a putative protein tyrosine phosphatase gene mutated in human brain, breast, and prostate cancer. Science 275:1943-1947 (1997).

Lupski JR, Stankiewicz P: Genomic disorders: molecular mechanisms for rearrangements and conveyed phenotypes. PLoS Genet 1:e49 (2005).

Menko FH, Kneepkens CM, de Leeuw N, Peeters EA, Van Maldergem L, et al: Variable phenotypes associated with $10 \mathrm{q} 23$ microdeletions involving the PTEN and BMPR1A genes. Clin Genet 74:145-154 (2008).

Nevado J, Mergener R, Palomares-Bralo M, Souza KR, Vallespín E, et al: New microdeletion and microduplication syndromes: a comprehensive review. Genet Mol Biol 37 Suppl 1:210219 (2014).

Petrova E, Neuner C, Haaf T, Schmid M, Wirbelauer J, et al: A boy with an LCR3/4-flanked 10q22.3q23.2 microdeletion and uncommon phenotypic features. Mol Syndromol 5:19-24 (2014).

Posey JE, Harel T, Liu P, Rosenfeld JA, James RA, et al: Resolution of disease phenotypes resulting from multilocus genomic variation. $\mathrm{N}$ Engl J Med 376:21-31 (2017).

Reddy KS, Mardach R, Bass H: Oligoarray (105K) CGH analysis of chromosome microdeletions within 10q22.1q24.32. Cytogenet Genome Res 132:113-120 (2011).

Coelho Molck/Simioni/Paiva Vieira/ Paoli Monteiro/Gil-da-Silva-Lopes
166 Mol Syndromol 2017;8:161-167 DOI: $10.1159 / 000469965$ 
Saito H, Yamamura KI, Suzuki N: Reduced bone morphogenetic protein receptor type $1 \mathrm{~A}$ signaling in neural-crest-derived cells causes facial dysmorphism. Dis Model Mech 5:948955 (2012).

Singh S, Aftimos S, George A, Love DR: Interstitial deletion of 10q23.1 and confirmation of three 10qdel syndromes. Singapore Med J 52:e143-146 (2011).

Slavotinek AM: Novel microdeletion syndromes detected by chromosome microarrays. Hum Genet 124:1-17 (2008).

van Bon BW, Balciuniene J, Fruhman G, Nagamani SC, Broome DL, et al: The phenotype of recurrent $10 \mathrm{q} 22 \mathrm{q} 23$ deletions and duplications. Eur J Hum Genet 19:400-408 (2011).
Vasan RS, Glazer NL, Felix JF, Lieb W, Wild PS, et al: Genetic variants associated with cardiac structure and function: a meta-analysis and replication of genome-wide association data. JAMA 302:168-178 (2009).

Vatta M, Stetson SJ, Perez-Verdia A, Entman ML, Noon GP, et al: Molecular remodeling of dystrophin in patients with end-stage cardiomyopathies and reversal in patients on assistance-device therapy. Lancet 359:936-941 (2002).
Yamazaki M, Araki K, Shibata A, Mishina M, et al: Molecular cloning of a cDNA encoding a novel member of the mouse glutamate receptor channel family. Biochem Biophys Res Commun 183:886-892 (1992).

Zhang W, St-Gelais F, Grabner CP, Trinidad JC, Sumioka A, et al: A transmembrane accessory subunit that modulates kainate-type glutamate receptors. Neuron 61:385-396 (2009).

Zhou XP, Waite KA, Pilarski R, Hampel H, Fernandez MJ, et al: Germline PTEN promoter mutations and deletions in Cowden/Bannayan-Riley-Ruvalcaba syndrome result in aberrant PTEN protein and dysregulation of the phosphoinositol-3-kinase/Akt pathway. Am J Hum Genet 73:404-411 (2003). 